PROF. SANDRA AMOR (Orcid ID : 0000-0001-6169-9845)

DR. DAVID BAKER (Orcid ID : 0000-0002-8872-8711)

Article type : Review

\title{
Innate immunity during SARS-CoV-2: evasion strategies and activation trigger hypoxia and vascular damage
}

\section{Sandra Amor',2, Laura Fernández Blanco', David Baker²}

1Pathology Department, VUmc, Amsterdam UMC, Amsterdam, The Netherlands

2Blizard Institute, Barts and The London School of Medicine and Dentistry, Queen Mary University of London, United Kingdom

Running head: Innate immunity in SARS-CoV-2 infection

Corresponding author: Professor Sandra Amor, Dept Pathology, Amsterdam UMC Location VUmc, De Boelelaan 1117, 1081 HV Amsterdam, The Netherlands. Email: s.amor@amsterdamumc.nl; tel: 0031204442898.

This article has been accepted for publication and undergone full peer review but has not been through the copyediting, typesetting, pagination and proofreading process, which may lead to differences between this version and the Version of Record. Please cite this article as doi: $\underline{10.1111 / \text { cei. } 13523}$

This article is protected by copyright. All rights reserved 


\section{Abstract}

Innate immune sensing of viral molecular patterns is essential for development of antiviral responses. Like many viruses, SARS-CoV-2 has evolved strategies to circumvent innate immune detection including low CpG levels in the genome, glycosylation to shield essential elements including the receptor binding domain, RNA shielding and generation of viral proteins that actively impede anti-viral interferon responses. Together these strategies allow widespread infection and increased viral load. Despite the efforts of immune subversion, SARS-CoV-2 infection activates innate immune pathways inducing a robust type I/III interferon response, production of proinflammatory cytokines, and recruitment of neutrophils and myeloid cells. This may induce hyperinflammation or alternatively, effectively recruit adaptive immune responses that help clear the infection and prevent reinfection. The dysregulation of the renin-angiotensin system due to downregulation of angiotensin converting enzyme 2 , the receptor for SARS-CoV-2, together with the activation of type I/III interferon response, and inflammasome response converge to promote free radical production and oxidative stress. This exacerbates tissue damage in the respiratory system but also leads to widespread activation of coagulation pathways leading to thrombosis. Here, we review the current knowledge of the role of the innate immune response following SARSCoV-2 infection, much of which is based on the knowledge from SARS-CoV and other coronaviruses. Understanding how the virus subverts the initial immune response and how an aberrant innate immune response contributes to the respiratory and vascular damage in COVID-19 may help explain factors that contribute to the variety of clinical manifestations and outcome of SARS-CoV-2 infection.

Keywords: COVID-19, SARS-CoV-2, immunology, endothelia, inflammation

\section{Abbreviations}

ACE2 - angiotensin-converting enzyme 2; AIM - absent in melanoma; ARDS - acute respiratory distress syndrome; BST - bone marrow stromal antigen 2; CHOP - C/EBP homologous protein; CNS - central nervous system; COVID-19 - coronavirus disease 2019; DAMPs - damage-associated molecular patterns; DPP4 - dipeptidyl peptidase 4; DMV double membrane vesicles; DUB - deubiquitin; E - envelope; ER - endoplasmic reticulum; ERGIC - ER Golgi intermediate compartment; HCoV - human coronaviruses; HMGB1 - high mobility group box 1; IFN - interferon; IFIT - interferon-induced proteins with tetratricopeptide repeats; IKK - inhibitor-кB kinase; MAC - membrane attack complex; MBL mannose binding protein; IRF - interferon-regulatory factor; ISG - interferon stimulated genes; M - membrane; MDA5 - melanoma differentiation-associated gene 5; MERS-CoV - 
Middle East respiratory syndrome coronavirus; MAV - mitochondrial antiviral signalling protein; N - nucleocapsid; NET - neutrophil extracellular trap; NKאB - nuclear factor kappalight-chain-enhancer of activated B cells; NLR - Nod-like receptor; NLRP3 - Nod pyrin domain-containing 3; ORF - open reading frame; PAMPs - pathogen-associated molecular patterns; PERK - PRKR-like endoplasmic reticulum kinase; PLPro - papain like protease; PPR - pattern recognition receptors; RAGE - receptor for advanced glycation end products; RBD receptor-binding domain; RIG-1 - retinoic acid-inducible gene I; RLR - retinoic acid-like receptors; RTC - replicase-transcriptase complex; SARS-CoV - Severe acute respiratory syndrome coronavirus; SARS-CoV-2 - severe acute respiratory syndrome coronavirus 2, STAT - signal transducer and activator of transcription; STING - stimulator of interferon genes; TBK-1 - TANK-binding kinase-1; TLR - Toll-like receptors; UPR - unfolded protein response; URTI - upper respiratory tract infection; VWF - von Willebrand factor; ZAP - zinc finger antiviral protein. 


\section{Introduction}

The emergence in Wuhan China of a novel severe acute respiratory syndrome coronavirus 2 (SARS-CoV-2) triggered an epidemic of the coronavirus disease 2019 (COVID-19). As of September $9^{\text {th }} 2020$, the confirmed $27,761,748$ cases including 902,306 deaths have been reported worldwide (worldometers.info/coronavirus). At the end of January 2020, the WHO declared COVID-19 a pandemic and a global health emergency.

The family Coronaviridae is subdivided into Torovirinae and Coronavirinae that contains the genera Alphacoronavirus, Betacoronavirus, Gammacoronavirus, and Deltacoronavirus. The human coronaviruses (HCoV) belong to the alpha-CoV (HCoV-229E and HCoV-NL63) and beta-CoV (Middle East respiratory syndrome coronavirus-MERS-CoV, SARS-CoV, HCoV-OC43 and HCoV-HKU1) [Table $1 ;(1-11)]$. In comparison with most HCoVs that cause mild upper respiratory tract infections, SARS-CoV, MERS-CoV and SARS-CoV-2 induce severe pneumonia (12). The clinical presentation of COVID-19 ranges from mild 'flu-like' symptoms to severe respiratory failure and death although between $17.9-57 \%$ of SARS-CoV-2 infections are asymptomatic depending on the population (13). Common symptoms include fever, cough, fatigue, shortness of breath, headache and pneumonia. In addition, some patients develop gastrointestinal problems (14), and neurological manifestations, including headache, dizziness, hyposmia and hypogeusia. Age and comorbidities i.e., hypertension, chronic obstructive pulmonary disease, diabetes, obesity and cardiovascular disease predispose to more severe manifestations, including severe respiratory failure, septic shock, coagulation dysfunction, strokes, cardiovascular problems (15) and neurological manifestations (16). Although the origin and transmission of SARS-CoV-2 is unclear, genome sequencing reveals marked similarities with SARS-CoV (17). However, in comparison, SARS-CoV-2 spreads more quickly than SARS-CoV, likely due to the $10-20 \%$ fold higher in infectivity and transmissibility during the initial non-symptomatic period (4-5 days). In some cases, transmission has been reported after development of initial symptoms despite the presence of antibodies, (18) indicating that both, neutralising antibodies and $\mathrm{T}$ cell responses, are necessary to prevent reinfection and for protection (19). This is further supported by studies showing PD1+CD57+ $T$ cell exhaustion, depletion or inactivation is associated with viral persistence in severe cases (20).

SARS-CoV-2 is a positive-sense RNA (29,903 nucleotides) enveloped virus of 60 to $140 \mathrm{~nm}$ diameter (21). The envelope is studded with homotrimers spike proteins of 8-12 nm length that are heavily decorated with N-glycans [figure $1(22,23)]$. Similar to other HCoVs, SARSCoV-2 genome encodes for four structural proteins: the spike (S), membrane (M), envelope (E) and the nucleocapsid ( $N$ ) protein. The $5^{\prime}$ end of the genome is comprised of ORFa/ab, encoding 2 large polyproteins including the replicase protein crucial for self-generation of the

This article is protected by copyright. All rights reserved 
non-structural proteins (nsp) while ORFs 2-10 encode the viral structural proteins - spike, envelope, membrane and nucleocapsid, and the accessory proteins [figure 1b]. Differences between the structural, non-structural and accessory proteins of SARS-CoV-2 and other coronaviruses help to explain the high infectivity rate and the range of pathologies observed $(12,15,16)$. While knowledge of SARS-CoV2 is rapidly emerging, parallels with SARS-CoV, as well as ongoing sequencing data and antigenic typing will be crucial to understand the dynamics of the pandemic. SARS-CoV-2 cell entry is similar to SARS-CoV being mediated by the binding of the receptor-binding domain (RBD) of the $S 1$ protein, to the angiotensinconverting enzyme-2 (ACE-2), although other receptors such as CD147 and CD-SIGN have been reported [Table 1]. Docking of the RBD to the receptor and the action of furin, a serine protease that separates the S1 and S2 proteins exposes a second binding domain on S2 allowing membrane fusion. Binding of the $\mathrm{S}$ protein to ACE-2 requires priming by cell proteases - primarily TMPRSS2, however, TMPRSS2 is expressed by a subset of ACE2+ cells supporting the notion that the virus likely uses other host enzymes such as TMPRSS4, Iysosomal cathepsins and neuropilin-1 (24) to augment the impact of furin and expose the RDB thus promoting SARS-CoV-2 entry (11). The structural proteins $M, E$ and $N$ are crucial for stability of the viral genome and viral replication. The nsp and accessory proteins (25) encoded by 10 open reading frames (ORFs) have differing functions during viral replication [Table 2 (26-63] and many also act to deviate the innate immune response thus augmenting viral replication and spread. The degree to which the innate immune system is suppressed and evaded clearly determines the viral load and the host's outcome to infection, the clinical symptoms and the severity of the disease.

\section{Evading Pattern Recognition Receptors}

Following infection, viral RNA is sensed by several classes of pattern recognition receptors (PPRs). The retinoic acid-like receptors (RLRs) include retinoid inducible gene I (RIG-I) and melanoma differentiation-associated gene 5 (MDA5), Toll-like receptors (TLR) - classically 3, 7 and 8 that trigger IFN pathways and cytokines production [figure 2]. Once engaged these PPRs act downstream via the kinases TANK-binding kinase-1 (TBK1) and inhibitor- $\kappa$ B kinases (IKKs). Such triggering leads to the activation of the transcription factors interferonregulatory factor-3 (IRF3) and 7 (IRF7) and nuclear factor kappa-light-chain-enhancer of activated $B$ cells $\left(N F_{\kappa} B\right)$. These subsequently induce expression of type I IFNs (IFNa/ $\beta$ ) and interferon stimulated genes (ISGs) [figure 2] many of which have potent antiviral activities, as well as other proinflammatory mediators e.g. cytokines, chemokines and antimicrobial peptides that are essential to initiate the host innate and adaptive immune response. In addition, the absent in melanoma 2 (AIM2)-like receptors and NOD-like receptors (NLRs)

This article is protected by copyright. All rights reserved 
trigger the inflammasome and IL-1 $\beta$ and IL-18 production leading to pyroptosis [figure 2]. Other PPRs and downstream factors relevant to SARS-CoV infection subversion of innate immune responses include C-type lectins and the stimulator of interferon genes (STING). While the cGas/STING pathway is commonly associated with sensing cytosolic DNA, it is also activated following binding of enveloped viruses to host cells and cytosolic viral RNA $(64,65)$. Similar to TLRs and RLR, downstream, STING engages TBK1 to active IRF3 and/or NFKB inducing type I IFN and/or proinflammatory cytokines [figure 2].

Coronaviruses have evolved several strategies to escape such innate immune recognition allowing widespread replication. Such evasion includes evolution of low genomic CpG, RNA shielding, masking of potential key antigenic epitopes as well as inhibition of steps in the interferon type I/III pathways. Generally, the zinc finger antiviral protein (ZAP) specifically binds to and degrades CPG motifs in genomes of RNA viruses. In comparison with other viruses, SARS-CoV-2 has evolved the most extreme CPG deficiency of all betacoronavirus [Table 2, (26)] thereby evading ZAP action. This suggests that SARS-CoV-2 may have evolved under selective pressure in either a new host or tissues expressing high levels of ZAP (26). Another strategy to protect mRNA used by the host and many viruses is the processing of capping the $5^{\prime}$ end. For both host and virus RNA, capping limits degradation and importantly blocks recognition by cytosolic PPRs. Like many RNA viruses SARS-CoV-2 has exploited several mechanisms to protect the $5^{\prime}$ ends by a cap structure of RNA generated during replication. While some viruses snatch the caps from host RNA, SARS-CoV-2, like other coronaviruses uses its own capping machinery composed of nsp10, nsp13 and the dedicated enzyme nsp16 to generate 2'-0-methyltransferase caps [suppl figure 1, (41)]. SARS-CoV-2 yields RNA caps indistinguishable from cellular mRNAs caps thereby evading detection by MDA5 and IFIT activity that target RNA for degradation [figure 2]. The importance of such capping and viral replication is supported by studies of SARS-CoV in mice lacking 2'-O-MTase activity underscoring that MDA5 and the IFIT family are critical for IFN signalling (45). While counter-intuitive, SARS-CoV uses its endoribonuclease (nsp15) to cleave its own viral RNA in the cytosol that would otherwise act as PAMPs thus evading MDA5, protein kinase $R(P K R)$, and OAS/RNAse $L(44,66)$. Yet another strategy used by SARS-CoV-2 to protect the viral RNA and proteins generated during replication [suppl figure $1]$ is the use of replicase-transcriptase complex (RTC) or replication organelle, formed of double-membrane vesicles (33). The RTCs link with the ER-Golgi intermediate compartment (ERGIC) and Golgi apparatus shielding the virus during maturation [suppl figure 1]. Another immune evasion strategy utilized by coronaviruses is the use of glycans and likely other post translational modifications to mask immunogenic viral protein epitopes [figure $1 \mathrm{C}$ and $\mathrm{D}$ ]. The envelope of SARS-CoV-2 is studded with glycoprotein spikes comprised of homotrimers spike

This article is protected by copyright. All rights reserved 
proteins of 8-12 nm length that are heavily decorated with glycans. Each spike protein comprises of two subunits (S1 and S2) that each bear 22 glycan groups (49). Cell entry of the highly glycosylated S protein of SARS-CoV is promoted by DC-SIGN possibly augmenting virus uptake or aiding capture and transmission of SARS-CoV by DCs and macrophages (6-8). Similar to the spike protein, the other structural, non-structural and accessory proteins are also modified by glycosylation, palmitoylation, phosphorylation, SUMOylation and ADPribosylation (67). Conversely, some viral proteins e.g. nsp3, possess deubiquitinating (DUB) and deISGylation activity thereby interfering with host functions targetting those that are critical for signalling transduction of innate immunity (34). Insertion of the spike protein into cell membranes during replication is a key step for virus budding. Whilst this takes place in the RTC [suppl figure 1], receptor-bound spike proteins interact with TMPRSS2 expressed on the uninfected cell surface, mediates fusion between infected and uninfected cells promoting the formation of syncytia allowing the virus to spread to adjacent uninfected cells while evading detection by the immune response (68).

\section{SARS-CoV-2 subversion of innate immune responses}

In addition to strategies to evade PPR recognition, SARS-CoV-2 has also evolved strategies to inhibit steps in the pathway leading to type I/III IFN production. This may be especially relevant in the lungs where type IFN III (lambda) is considered to be more effective in controlling viral infections and critically affected in COVID-19. Knowledge arising from the study of other coronaviruses, especially SARS-CoV and MERS, has shown that many of the non-structural, structural and accessory proteins interfere with elements of the IFN pathway [Table 2, figure 2], essential for the development of effective immunity. IFN antagonism has been attributed to several of the structural, non-structural and accessory proteins that interfere with stimulator of interferon genes (STING)-TRAF3-TBK1 complex, thereby blocking STING/TBK1/IKKE-induced type I IFN production, STAT-1/2 translocation to the nucleus, IRF3, NFKB signalling as well as interfering with the actions of the ISG products including IFITs [Table 2]. As examples, nsp1, 4 and 6, and ORF6 interfere with STAT-1/2 signalling while nsp 10, 13 and 16 cap the viral RNA [Table 2] preventing recognition by RIG-I, MDA5 and IFITs. Nsp3 also acts by DUB proteins thereby preventing their activity such as RIG-I and other steps in the IFN pathways for which ubiquitination is essential. CoV PLPro (nsp 3) also interrupts the stimulator of interferon genes STING.TRAF3. TBK1 complex thereby blocking STING/TBK1/IKKE-type I IFN production $(32,34)$. As well as subversion of the IFN pathway, SARS-CoV ORF7a (also present in SARS-CoV-2) blocks the activity of tetherin also known as bone marrow stromal antigen 2 (BST-2) (58). BST2 acts by tethering budding viruses to the

This article is protected by copyright. All rights reserved 
cell membrane thus preventing its release from the cells. ORF7a removes this inhibition aiding the release of mature virions.

In summary, emerging evidence from SARS-CoV-2, and comparison with other SARS-Cov and MERS, reveals many strategies used to evade the innate immune response and subvert the interferon pathway. While this facilitates widespread viral replication increasing the viral load also promotes the viral cytopathic effects leading to tissue damage described below, likely leads to exacerbation and hyperinflammation of the innate immune response once triggered.

\section{Triggering Innate Immunity}

Despite immune evasion and subverting innate immune responses during early infection, SARS-CoV-2 effectively initiates immune signalling pathways. This is likely due to the increased viral load that exponentially produces viral RNA and viral proteins (pathogen associated molecular patterns - PAMPS), also induces cell damage that release damage associated molecular patterns (DAMPS) both of which trigger innate immune pathways.

Like SARS-CoV and NL63, SARS-CoV-2 uses the angiotensin (Ang)-converting enzyme2 (ACE2) as a cell receptor [Table 1], expressed on epithelia in renal, cardiovascular and gastrointestinal tract tissues, testes and on pneumocytes and vascular endothelia (66). ACE2 regulates the renin-angiotensin system (RAS) by balancing the conversion of angiotensin I to angiotensin 1-9 and angiotensin II to angiotensin 1-7. Binding of SARS-CoV-2 to ACE2 leads to endosome formation, reducing ACE2 expression on the cell surface [figures 3 and 4] and pushing the RAS system to a pro-inflammatory mode triggering production of reactive oxygen species, fibrosis, collagen deposition and a proinflammatory environment including IL- 6 and IL-8 production by macrophages and recruitment of neutrophils [figure 4]. Thus, binding and entry of SARS-CoV-2 via the ACE2 is likely to be the first step in a line of augmented and detrimental immune responses in COVID-19 that involves complement activation, innate immune activation via PAMPS and DAMPS, inflammasome activation and pyroptosis, NK cell activation, hyperactivation of macrophages, neutrophils and innate $\mathrm{T}$ cells and induction of a cytokine storm as discussed below.

\section{Complement}

SARS-CoV-2 is heavily decorated with glycans [figure 1] that are recognised by DC-SIGN and other lectins that facilitate viral uptake by dendritic cells. Glycans also activate the lectin complement pathway following binding of mannose binding protein (MBP) to SARS-CoV-2 viral proteins expressed on infected cells [figures 1 and 2]. Pathology studies and transcriptional profiles of tissues from COVID-19 cases reveal robust activation of the complement system with deposition of $M B L, C 4 d, C 3$ and $C 5 b-9$ forming the membrane 
attack complex (MAC) in alveolar and epithelial cells $(68,69)$ [figure 4]. In addition, C4d and C5b-9 deposits in lung and skin microvasculature co-localised with spike glycoproteins indicates systemic complement activation, supporting the role of complement in tissue damage (68). Importantly, activation of the lectin, as well as the classical pathway following antibody binding to viral proteins, likely contributes to cell damage [figure 4, (70)] by either direct complement mediated lysis or via antibody dependent cell mediated cytotoxicity. Of relevance to the coagulation dysfunction, thrombosis and vascular damage observed following SARS-CoV-2 infection is that complement components induce secretion of von Willebrand factor (71) but also promotes monocyte and neutrophil recruitment as well as stimulates NET formation (72) that in turn perpetuates complement activation [figure 4]. Complement may thus contribute to widespread tissue damage in SARS-CoV-2 infected cases. The pathogenic role of complement in disease is supported by findings in mice. For example, mice deficient in C3 had similar viral load as wildtype mice but lacked the overt pathology with fewer neutrophils and macrophages in the lung (73). Thus, while complement activation is not required for control of virus infection it likely plays a key role in the tissue damage.

\section{PAMPS and DAMPS mediate innate immune signalling}

Infected pneumocytes and other permissible cells undergo cell damage and cell death releasing virally-associated molecules so-called 'pathogen associated molecular patterns' (PAMPS). In addition, intracellular components released due to damage so-called 'damage or danger associated molecular patterns' (DAMPS) include ATP, oxidized lipids, heat shock proteins and other components associated with regulated cell death programmes including apoptosis, autophagy, necroptosis, and pyroptosis [figure 3 and 4]. Thus, both DAMPS and PAMPS contribute to innate immune activation in COVID-19.

RNA viruses trigger several TLRs, including TLR7/8 and TLR3, and elegant molecular in silco docking studies show that the spike protein of SARS-CoV-2 can bind to TLR1, TLR4, and TLR6 (74) (figure 3) whereas in vitro the SARS-CoV spike protein triggers NFKB activation and IL-8 production via TLR2 signalling in human peripheral blood mononuclear cells (75). In mice in which specific points in the TLR pathway were deleted i.e. TLR3 ${ }^{-/-}$, TLR4 ${ }^{-/-}$, and TRAM $^{-/-}$, animals were more susceptible to SARS-CoV infection, although the clinical severity of disease was dramatically reduced. This was in direct contrast to deficiency in TRIF, the TLR adaptor protein [figure 3] in which TRIF-/- mice developed severe disease, exacerbated influx of macrophages and neutrophils, and lung pathology indicative of COVID-19 pathology. Thus, a balanced response to infection via TLR3 pathway is essential to trigger a protective response to SARS-CoV (76). This study also supports the idea that in addition, PAMPS,

This article is protected by copyright. All rights reserved 
immune pathways triggered by DAMPS such as oxidised phospholipids, high mobility group box 1 (HMGB1), histones, heat shock proteins and adenosine triphosphate released by damaged cells may contribute to COVID-19 outcome [figures 3 and 4]. In addition to RIG-I, MDA5 and MAVS, RNA viruses are also sensed by the stimulator of interferon genes (STING) that is activated by cGAMP when enveloped RNA viruses interact with the host membranes (64). Downstream, STING engages TBK1 that actives IRF3 and/or NFKB inducing type 1 IFN and/or proinflammatory cytokines. That hyperactivation of STING contributes to severe COVID-19 as has been hypothesised by Berthelot and Lioté (77). These authors present several lines of evidence, the strongest being that gain of function mutations of STING associated with hyperactivation of type I IFN induces the disease SAVI (STING-Associated Vasculopathy with onset in Infancy). Affected children with SAVI present with pulmonary inflammation, vasculitis and endothelial-cell dysfunction that mimics many aspects of COVID19 (78). Furthermore, STING polymorphisms are associated with ageing-related diseases such as obesity and cardiovascular disease, possibility explaining the impact of comorbidities and development of severe COVID-19 (78). Also, in bats in which SARS-CoV-2 may have arisen, STING activation and thus consequently IFN $\beta$, is blunted (79), likely aiding viral replication and spread as observed in early SARS-CoV-2 infection in humans. That DAMPS released due to viral cytotoxicity may contribute to severe COVID-19 which is best exemplified by HMBG1 released by damaged and dying cells as well as activated innate immune cells especially in sepsis (80). Depending on its conformation HMGB1 triggers TLR2, TLR4 and TLR9, the receptor for advanced glycation end-products (RAGE) and triggering receptor expressed in myeloid cells 1 (TREM-1) [figure 3]. In mice, intratracheal administration of HMGB1 activates mitogen-activated protein kinase (MAPK) and NFKB, inducing proinflammatory cytokines, activating the endothelium and recruiting neutrophils in the lung - key pathological features of severe COVID-19 $(80,81)$. HMGB1, and especially the platelet-derived source may play a crucial role in SARS-CoV-2 vascular damage since HMGB1I- mice display delayed coagulation, reduced thrombus formation and platelet aggregation (82). Furthermore, blocking HMGB1 is beneficial in experimental lung injury and sepsis, suggesting therapies targeting HMGB1 might also be beneficial in severe COVID-19 (83).

\section{Inflammasome activation and pyroptosis}

Studies of peripheral blood and post-mortem tissues from severe COVID-19 cases reveal high

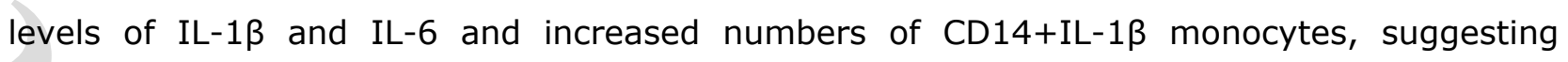
activation of the Nod-like receptor family, pyrin domain-containing 3 (NLRP3) inflammasome pathway (84). Activation of the NLRP3 inflammasome, essential for effective antiviral immune responses, is elicited by several factors associated with SARS-CoV infection including RAS

This article is protected by copyright. All rights reserved 
disbalance, engagement of PPR, TNFR and IFNAR, mitochondrial ROS production, complement components including MAC, as well as SARS-CoV viral proteins such as ORF3a, N and E [figure 3, Table 2]. As a consequence, NLRP3 interaction with adaptor apoptosis specklike protein (ASC) recruits and activates procaspase-1, processing pro-IL-1 $\beta$ and pro-IL-18 to the activate forms [figure 3]. This drives the propyroptotic factor gasdermin D (GSDMD) formation of pores in the cell membrane, i.e. pyroptosis that facilitates the release of proinflammatory cytokines. The pores also aid the release of cellular DAMPS such as HMGB1, and viral PAMPS that further exacerbate inflammation suggesting that targeting the NLRP3 pathway might be beneficial in severe COVID-19 cases.

\section{Hyperinflammation and severe COVID-19}

The delayed interferon response, increased viral load and virus dissemination, coupled with the release of DAMPS and PAMPs lead to activation of several innate immune pathways. Following infection, pneumocytes, epithelial and alveolar cells, and infiltrating monocytemacrophages and neutrophils likely produce the first wave of TNF $\alpha$, IL-6, IP-10, MCP-1, MIP$1 \alpha$ and RANTES production $(87,88)$. Hyperinflammation is likely promoted by comorbidities due to increased ACE2 expression, concurrent bacterial infections and ageing as well as a direct effect of SARS-CoV-2 replication since virus-host interactome studies reveal that SARSCoV-2 nsp10 regulates the NFKB repressor factor NKRF, facilitating IL-8 production (89). This is followed by a second wave of cell recruitment including NK cells that produce IFN $\gamma$ and further recruitment of (alternatively activated) monocytes/macrophages and neutrophils [figure 4] as observed in bronchial lavages, post-mortem tissues and peripheral blood studies $(88,89)$. NK cells are key players in disease outcome of infection, critically balancing the direct response to the virus by eliminating infected cells while also augmenting tissue damage [figure 4]. Likely aided by IFN $\gamma$ induction by NK cells, hyperinflammation in severe COVID-19 is also characterised by recruitment of immature and mature human monocyte-derived DCs that harbour SARS-CoV infection, however, infection is abortive and mature virions are not released. During infection, DCs express only low levels of cytokines likely due to innate immune subversion strategies. The sustained activation of infiltrating monocytes and monocyte-derived macrophages (90) observed in severe COVID-19 cases is likely driven by a number of factors including oxidative stress, anti-SARS-CoV-2 antibody:antigen complexes, NLRP3 inflammasome activation, and complement activation that converge to sustain an aberrant hyperinflammatory response, or cytokine storm (91). Following SARS-CoV-2 infection, one of the first innate immune cells to infiltrate into the tissues are neutrophils, likely recruited by CXCL2 and CXCL8 generated by infected cells (92). While neutrophils do not clear viral particles, they phagocytose apoptotic bodies containing virus and debris,

This article is protected by copyright. All rights reserved 
releasing proteolytic enzymes, antimicrobial peptides, matrix metalloproteinases and high levels of ROS to inactivate viruses. A key function of neutrophils relevant to the pathology of SARS-CoV-2 is the production of neutrophil extracellular traps (NETs) generated in response to endothelial damage, ROS production, IL-1 $\beta$ production and virus replication [figure 4, reviewed in (93)]. The formation of NETs by neutrophils are aided by activated platelets associated with damaged endothelial cells that further activate the complement, fuelling the coagulation cascade and thrombi formation. While the NETs act to prevent further spread of the virus they trigger platelet activation and bind erythrocytes thereby promoting (micro)thrombi formation [figure 4].

\section{SARS-CoV-2 is a vascular and coagulation disease}

While respiratory damage and complications are the major clinical signs of severe COVID-19 many tissues and organs are affected often prior to, or independently of lung pathology, for example Kawasaki-like vascular disease in children (94). Clinical, post-mortem studies and experimental animal models of SARS-CoV reveal infection of endothelial cells and the widespread damage of endothelial cells, vascular dysfunction and thrombosis $(94,95)$ that are emerging as a common pathological feature of SARS-CoV-2 infection. The link between SARS-CoV-2 infection, vascular damage and thrombosis is evidenced by high levels of Ddimers in $20-40 \%$ critically ill patients likely produced in an attempt to dissolve thrombotic clots. The endothelial cell damage is supported by the finding that endothelial cells express ACE2 and are thus permissible to SARS-CoV-2 infection (94). Thus, infection not only leads to reduced ACE2 in endothelial cells, but also direct viral cytopathic damage and increased vascular permeability [figure 4], although more recent data challenge this view suggesting that pericytes and not endothelial cells are permissible to infection and viral induced damage $(95,96)$. Damage of endothelial cells and pericytes leads to vascular permeability in severe COVID-19 that is likely amplified by activation of complement components widely expressed in post-mortem tissues of COVID-19 cases $(68,69)$. Disruption of the vascular barrier and endothelial cell exposure to IL-1 $\beta, T N F \alpha$ and ROS increase expression of P-selectin, von Willebrand factor ( $V W F$ ) and fibrinogen, and attracting platelets that trigger expression of tissue factor [figure 4]. Together, this sequence triggers the coagulation cascade and explains the finding of increased D-dimer and fibrin, abnormal clotting times in severe COVID-19 cases and widespread disseminated thrombi in post-mortem tissues.

\section{Disease severity, comorbidities and innate immunity}

SARS-CoV-2 exploits many strategies to subvert innate immune responses allowing the virus to replicate and disseminate within the host. The extent to which the virus replicates within 
the host, and the efficacy of the host innate immune response to eradicate the infection and trigger effective adaptive immune responses, but not hyper-responsiveness of innate immunity, strongly determines the disease outcome [Table 3]. The severity of infection has been linked to age, smoking, comorbidities such as cancer, immune suppression, autoimmune diseases, inflammatory disease, neurodegenerative diseases, obesity, gender and race (97-106). For example, in a large cohort of 72,314 cases the case fatality ratio for over 80 years was $14.8 \%$ versus $2.3 \%$ in the total cohort (97). This is likely higher due to inflamm-ageing, an aberrant innate immune response such as lower production of IFN $\beta$ (98), increased oxidative stress (99) and sensence of macrophages that become less effective in their reparative functions with age (100). Likewise, viral load, obesity, gender, race, blood groups and comorbidities have all been reported to influence the response to SARS-CoV-2 infection, [Table 4; (101-112)] although few studies have fully examined the extent to which subversion and activation of innate immune components contribute to susceptibility in these cases.

\section{Future perspectives}

Understanding the innate immune factors that exacerbate the vascular complications will be crucial to control severe disease following SARS-CoV-2 infection. Rapidly emerging studies reveal the extent to which therapeutic approaches for other viral infections and inflammatory diseases can be repurposed to target innate immunity to treat COVID-19 patients $(113,114)$. Likewise, novel approaches have been put forward to target the susceptible ageing population or those with comorbidities. One approach under investigation is to re-establish the youthful function of macrophages and repair mechanisms using metformin, a drug used in type 2 diabetes that has been shown to attenuate hallmarks of ageing (115). In a retrospective study of 25,326 subjects tested for COVID-19 while diabetes was reported to be an independent risk factor for COVID-19-related mortality (116) the risk in subjects taking metformin was significantly reduced (OR 0.33 ; 95\%CI $0.13-0.84$ ) suggesting metformin might be protective in high risk populations (ref) especially since metformin has also been reported to suppress neutrophil induced NETosis in vitro and reduce circulating NETosis biomarkers in vivo (117). Thus, metformin and other drugs such as niacin (118) that rejuvenate the innate immune system may be useful in COVID-19.

\section{Funding}

This received study received no funding.

\section{Acknowledgements}

This article is protected by copyright. All rights reserved 
The authors thank Alison Schroeer (Schroeer Scientific Illustration) for advice and assistance concerning the figure production and Dr Roger D. Seheult, (MedCram) for invaluable insights relating to pulmonary medicine and COVID-19. SA wrote the paper, LFB produced the figures 1,2 and the supplementary figure and made the first draft of the paper. DB made the second draft. All authors read and approved the final draft.

\section{Competing Statement Declarations}

DB and SA have received compensation for consultancies, presentations and advisory board activities but no companies were involved in the decision to write and submit this manuscript. LFB has nothing to disclose. SA has received consultancy from Novartis and Roche. DB has received compensation for activities related to Canbex therapeutics, InMune Biol, Lundbeck, Japan tobacco, Merck, Novartis.

This article is protected by copyright. All rights reserved 


\section{References}

1. Yeager $\mathrm{CL}$, Ashmun RA, Williams RK, et al. Human aminopeptidase $\mathrm{N}$ is a receptor for human coronavirus 229E. Nature. 1992;357:420-22.

2. Bertram S, Dijkman R, Habjan M, et al. TMPRSS2 Activates the Human Coronavirus 229E for Cathepsin-Independent Host Cell Entry and Is Expressed in Viral Target Cells in the Respiratory Epithelium. J Virol. 2013;87:6150-60.

3. Bonavia A, Arbour N, Yong VW, Talbot PJ. Infection of primary cultures of human neural cells by human coronaviruses 229E and OC43. J Virol. 1997; 71:800-6.

4. Collins AR. HLA Class I Antigen Serves as a Receptor for Human Coronavirus OC43. Immunol Invest. 1993;22:95-103.

5. Vlasak R, Luytjes W, Spaan W, Palese P. Human and bovine coronaviruses recognize sialic acid-containing receptors similar to those of influenza $C$ viruses. Proc Natl Acad Sci. 1988;85:4526-9.

6. Marzi A, Gramberg T, Simmons G, et al. DC-SIGN and DC-SIGNR Interact with the Glycoprotein of Marburg Virus and the S Protein of Severe Acute Respiratory Syndrome Coronavirus. J Virol. 2004;78:12090-95.

7. Jeffers SA, Tusell SM, Gillim-Ross L, et al. CD209L (L-SIGN) is a receptor for severe acute respiratory syndrome coronavirus. Proc Natl Acad Sci U S A. 2004;101:15748-53.

8. Hofmann H, Pyrc K, Van Der Hoek L, Geier M, Berkhout B, Pöhlmann S. Human coronavirus NL63 employs the severe acute respiratory syndrome coronavirus receptor for cellular entry. Proc Natl Acad Sci U S A. 2005;102:7988-93.

9. Chan CM, Lau SKP, Woo PCY, et al. Identification of Major Histocompatibility Complex Class I C Molecule as an Attachment Factor That Facilitates Coronavirus HKU1 Spike-Mediated Infection. J Virol. 2009;83:1026-35.

10. Millet JK, Whittaker GR. Host cell entry of Middle East respiratory syndrome coronavirus after two-step, furin-mediated activation of the spike protein. Proc Natl Acad Sci. 2014;111:15214-19.

11. Hoffmann M, Kleine-Weber H, Pöhlmann S. A Multibasic Cleavage Site in the Spike Protein of SARS-CoV-2 Is Essential for Infection of Human Lung Cells. Mol Cell. 2020;78:779-84.

12. Chen G, Wu D, Guo W, et al. Clinical and immunologic features in severe and moderate Coronavirus Disease 2019. J Clin Invest. 2020;130:2620-9.

13. Lee S, Meyler P, Mozel M, Tauh T, Merchant R. Asymptomatic carriage and transmission of SARS-CoV-2: What do we know? Can J Anaesth. 2020;67:1424-30.

14. Rokkas T. Gastrointestinal involvement in COVID-19: a systematic review and meta-analysis. Ann Gastroenterol. 2020;33:355-65

15. Hendren NS, Drazner MH, Bozkurt B, Cooper LT. Description and Proposed Management of 
the Acute COVID-19 Cardiovascular Syndrome. Circulation. 2020;141:1903-14.

16. Ellul MA, Benjamin L, Singh B, et al. Neurological associations of COVID-19. Lancet Neurol. 2020;19:767-83.

17. Yoshimoto FK. The Proteins of Severe Acute Respiratory Syndrome Coronavirus-2 (SARS CoV-2 or n-COV19), the Cause of COVID-19. Protein J. 2020;39:198-216.

18. Thevarajan I, Nguyen THO, Koutsakos M, et al. Breadth of concomitant immune responses prior to patient recovery: a case report of non-severe COVID-19. Nat Med. 2020;26:453-5.

19. Grifoni A, Weiskopf D, Ramirez SI, et al. Targets of T Cell Responses to SARS-CoV-2 Coronavirus in Humans with COVID-19 Disease and Unexposed Individuals. Cell. 2020;181:1489-1501.

20. De Biasi S, Meschiari M, Gibellini L, et al. Marked T cell activation, senescence, exhaustion and skewing towards TH17 in patients with COVID-19 pneumonia. Nat Commun. 2020;11:3434.

21. Lu R, Zhao X, Li J, et al. Genomic characterisation and epidemiology of 2019 novel coronavirus: implications for virus origins and receptor binding. Lancet. 2020;395;565-74.

22. Grant OC, Montgomery D, Ito K, Woods RJ. 3D Models of glycosylated SARS-CoV-2 spike protein suggest challenges and opportunities for vaccine development. bioRxiv. 2020. DOI: $10.1101 / 2020.04 .07 .030445$

23. Walls AC, Tortorici MA, Frenz B, et al. Glycan shield and epitope masking of a coronavirus spike protein observed by cryo-electron microscopy. Nat Struct Mol Biol. 2016;23:899-905.

24. Daly JL, Simonetti B, Antón-Plágaro C, et al. Neuropilin-1 is a host factor for SARS-CoV-2 infection. bioRxiv. 2020. DOI: 10.1101/2020.07.17.209288

25. Liu DX, Fung TS, Chong KK-L, Shukla A, Hilgenfeld R. Accessory proteins of SARS-CoV and other coronaviruses. Antiviral Res. 2014;109:97-109.

26. Xia X. Extreme genomic CpG deficiency in SARS-CoV-2 and evasion of host antiviral defense. Mol Biol Evol. 2020;37:2699-705

27. Jauregui AR, Savalia D, Lowry VK, Farrell CM, Wathelet MG. Identification of Residues of SARSCoV nsp1 That Differentially Affect Inhibition of Gene Expression and Antiviral Signaling. Li K, editor. PLoS One. 2013;8:e62416.

28. Wathelet MG, Orr M, Frieman MB, Baric RS. Severe Acute Respiratory Syndrome Coronavirus Evades Antiviral Signaling: Role of nsp1 and Rational Design of an Attenuated Strain. J Virol. 2007;81:11620-33.

29. Kamitani W, Narayanan K, Huang C, et al. Severe acute respiratory syndrome coronavirus nsp1 protein suppresses host gene expression by promoting host mRNA degradation. Proc Natl Acad Sci. 2006;103:12885-12890.

30. Graham RL, Sims AC, Brockway SM, Baric RS, Denison MR. The nsp2 Replicase Proteins of 
Murine Hepatitis Virus and Severe Acute Respiratory Syndrome Coronavirus Are Dispensable for Viral Replication. J Virol 2005;79:13399-411.

31. Cornillez-Ty CT, Liao L, Yates 3rd JR, Kuhn P, Buchmeier MJ. Severe acute respiratory syndrome coronavirus nonstructural protein 2 interacts with a host protein complex involved in mitochondrial biogenesis and intracellular signaling. J Virol 2009,83:10314-8.

32. Báez-Santos YM, St. John SE, Mesecar AD. The SARS-coronavirus papain-like protease: Structure, function and inhibition by designed antiviral compounds. Antiviral Res. 2015;115:21-38.

33. Angelini MM, Akhlaghpour M, Neuman BW, Buchmeier MJ. Severe Acute Respiratory Syndrome Coronavirus Nonstructural Proteins 3, 4, and 6 Induce Double-Membrane Vesicles. MBio. 2013; 4(4):e00524-13

34. Chen $X$, Yang $X$, Zheng $Y$, Yang $Y$, Xing $Y$, Chen Z. SARS coronavirus papain-like protease inhibits the type I interferon signaling pathway through interaction with the STING-TRAF3TBK1 complex. Protein Cell. 2014;5:369-81.

35. Lin C-W, Lin K-H, Hsieh T-H, Shiu S-Y, Li J-Y. Severe acute respiratory syndrome coronavirus 3C-like protease-induced apoptosis. FEMS Immunol Med Microbiol. 2006;46:375-80.

36. Kirchdoerfer RN, Ward AB. Structure of the SARS-CoV nsp12 polymerase bound to nsp7 and nsp8 co-factors. Nat Commun. 2019;10:2342.

37. Sutton G, Fry E, Carter L, et al. The nsp9 replicase protein of SARS-coronavirus, structure and functional insights. Structure. 2004;12:341-53.

38. Egloff M-P, Ferron F, Campanacci V, et al. The severe acute respiratory syndrome-coronavirus replicative protein nsp9 is a single-stranded RNA-binding subunit unique in the RNA virus world. Proc Natl Acad Sci U S A. 2004;101:3792-66

39. Ma $Y, W u L$, Shaw N, et al. Structural basis and functional analysis of the SARS coronavirus nsp14-nsp10 complex. Proc Natl Acad Sci U S A. 2015;112:9436-41.

40. Li Q, Wang L, Dong C, et al. The interaction of the SARS coronavirus non-structural protein 10 with the cellular oxido-reductase system causes an extensive cytopathic effect. J Clin Virol. 2005;34:133-9.

41. Decroly E, Debarnot C, Ferron F, et al. Crystal Structure and Functional Analysis of the SARSCoronavirus RNA Cap 2'-O-Methyltransferase nsp10/nsp16 Complex. Rey FA, editor. PLoS Pathog. 2011;7:e1002059.

42. Ivanov KA, Thiel V, Dobbe JC, van der Meer Y, Snijder EJ, Ziebuhr J. Multiple Enzymatic Activities Associated with Severe Acute Respiratory Syndrome Coronavirus Helicase. J Virol. 2004;78:5619-32.

43. Minskaia $E$, Hertzig $T$, Gorbalenya $A E$, et al. Discovery of an RNA virus $3^{\prime}->5^{\prime}$ exoribonuclease that is critically involved in coronavirus RNA synthesis. Proc Natl Acad Sci $U$ S A. 
2006;103:5108-13.

44. Deng $X$, Hackbart M, Mettelman RC, et al. Coronavirus nonstructural protein 15 mediates evasion of dsRNA sensors and limits apoptosis in macrophages. Proc Natl Acad Sci U S A. 2017;114:4251-60.

45. Menachery VD, Yount $B L$, Josset $L$, et al. Attenuation and Restoration of Severe Acute Respiratory Syndrome Coronavirus Mutant Lacking 2'-O-Methyltransferase Activity. J Virol. 2014;88:4251-64.

46. Menachery VD, Debbink K, Baric RS. Coronavirus non-structural protein 16: Evasion, attenuation, and possible treatments. Virus Res. 2014;194:191-9.

47. Walls AC, Park Y-J, Tortorici MA, Wall A, McGuire AT, Veesler D. Structure, Function, and Antigenicity of the SARS-CoV-2 Spike Glycoprotein. Cell. 2020;81:281-292.

48. Imai $Y$, Kuba K, Penninger JM. The discovery of angiotensin-converting enzyme 2 and its role in acute lung injury in mice. Exp Physiol 2008;93:543-8.

49. Watanabe Y, Allen JD, Wrapp D, McLellan JS, Crispin M. Site-specific glycan analysis of the SARS-CoV-2 spike. Science. 2020;369:330-3

50. Padhan K, Tanwar C, Hussain A, et al. Severe acute respiratory syndrome coronavirus Orf3a protein interacts with caveolin. J Gen Virol 2007;88:3067-77

51. Kopecky-Bromberg SA, Martínez-Sobrido L, Frieman M, Baric RA, Palese P. Severe acute respiratory syndrome coronavirus open reading frame (ORF) 3b, ORF 6, and nucleocapsid proteins function as interferon antagonists. J Virol. 2007;81:548-57.

52. Minakshi R, Padhan K, Rani M, Khan N, Ahmad F, Jameel S. The SARS Coronavirus 3a Protein Causes Endoplasmic Reticulum Stress and Induces Ligand-Independent Downregulation of the Type 1 Interferon Receptor. PLoS One. 2009;4:e8342.

53. Nieto-Torres JL, DeDiego ML, Verdiá-Báguena C, et al. Severe Acute Respiratory Syndrome Coronavirus Envelope Protein Ion Channel Activity Promotes Virus Fitness and Pathogenesis. PLoS Pathog. 2014;10:e1004077.

54. Álvarez E, DeDiego ML, Nieto-Torres JL, Jiménez-Guardeño JM, Marcos-Villar L, Enjuanes L. The envelope protein of severe acute respiratory syndrome coronavirus interacts with the non-structural protein 3 and is ubiquitinated. Virology. 2010;402:281-91.

55. Fang X, Gao J, Zheng $H$, et al. The membrane protein of SARS-CoV suppresses NF-kappaB activation. J Med Virol. 2007;79:1431-9.

56. Siu K-L, Kok K-H, Ng M-HJ, et al. Severe acute respiratory syndrome coronavirus M protein inhibits type I interferon production by impeding the formation of TRAF3.TANK.TBK1/IKKepsilon complex. J Biol Chem. 2009;284:16202-9.

57. Chan C-M, Ma C-W, Chan W-Y, Chan HYE. The SARS-Coronavirus Membrane protein induces apoptosis through modulating the Akt survival pathway. Arch Biochem Biophys. 
2007;459:197-207.

58. Taylor JK, Coleman CM, Postel S, et al. Severe Acute Respiratory Syndrome Coronavirus ORF7a Inhibits Bone Marrow Stromal Antigen 2 Virion Tethering through a Novel Mechanism of Glycosylation Interference. J Virol. 2015;89:11820-33.

59. Yuan $X$, Wu J, Shan $Y$, et al. SARS coronavirus 7a protein blocks cell cycle progression at G0/G1 phase via the cyclin D3/pRb pathway. Virology. 2006;346:74-85.

60. Schaecher SR, Mackenzie JM, Pekosz A. The ORF7b Protein of Severe Acute Respiratory Syndrome Coronavirus (SARS-CoV) Is Expressed in Virus-Infected Cells and Incorporated into SARS-CoV Particles. J Virol. 2007;81:718-31.

61. Zhang $Y$, Zhang J, Chen $Y$, et al. The ORF8 Protein of SARS-CoV-2 Mediates Immune Evasion through Potently Downregulating MHC-I. bioRxiv. 2020 Jan 1; https://www.biorxiv.org/content/10.1101/2020.05.24.111823v1

62. Hu Y, Li W, Gao T, et al. The Severe Acute Respiratory Syndrome Coronavirus Nucleocapsid Inhibits Type I Interferon Production by Interfering with TRIM25-Mediated RIG-I Ubiquitination. J Virol. 2017;91:e02143-16.

63. Shi C-S, Qi H-Y, Boularan C, et al. SARS-Coronavirus Open Reading Frame-9b Suppresses Innate Immunity by Targeting Mitochondria and the MAVS/TRAF3/TRAF6 Signalosome. J Immunol. 2014;193:3080-9.

64. Ma Z, Damania B. The cGAS-STING Defense Pathway and Its Counteraction by Viruses. Cell Host Microbe. 2016;19:150-8.

65. Bai J, Liu F. The cGAS-cGAMP-STING Pathway: A Molecular Link Between Immunity and Metabolism. Diabetes. 2019;68:1099-108.

66. Posthuma CC, te Velthuis AJW, Snijder EJ. Nidovirus RNA polymerases: Complex enzymes handling exceptional RNA genomes. Virus Res. 2017;234:58-73.

67. Fung TS, Liu DX. Post-translational modifications of coronavirus proteins: roles and function. Future Virol. 2018;13:405-30.

68. Xia S, Liu M, Wang C, et al. Inhibition of SARS-CoV-2 (previously 2019-nCoV) infection by a highly potent pan-coronavirus fusion inhibitor targeting its spike protein that harbors a high capacity to mediate membrane fusion. Cell Res. 2020;30:343-55

67. Shang J, Wan Y, Luo C, et al. Cell entry mechanisms of SARS-CoV-2. Proc Natl Acad Sci. 2020;117:11727-34.

68. Magro C, Mulvey JJ, Berlin D, et al. Complement associated microvascular injury and thrombosis in the pathogenesis of severe COVID-19 infection: A report of five cases. Transl Res. 2020;220:1-13.

69. Ramlall V, Thangaraj $\mathrm{P}$, Meydan $\mathrm{C}$, et al. Identification of Immune complement function as a determinant of adverse SARS-CoV-2 infection outcome. medRxiv. 2020 Jan 
1;2020.05.05.20092452. DOI: 10.1101/2020.05.05.20092452

70. Ip WKE, Chan KH, Law HKW, et al. Mannose-Binding Lectin in Severe Acute Respiratory Syndrome Coronavirus Infection. J Infect Dis. 2005;191:1697-704.

71. Hattori R., Hamilton K.K., McEver R.P. SPJ. Complement proteins C5b-9 induce secretion of high molecular weight multimers of endothelial von Willebrand factor and translocation of granule membrane protein GMP-140 to the cell surface. J Biol Chem. 1989;264:9053-9060.

72. de Bont CM, Boelens WC, Pruijn GJM. NETosis, complement, and coagulation: a triangular relationship. Cell Mol Immunol. 2019;16:19-27.

73. Gralinski LE, Sheahan TP, Morrison TE, et al. Complement Activation Contributes to Severe Acute Respiratory Syndrome Coronavirus Pathogenesis. MBio. 2018;9:e01753-18.

74. Choudhury A, Mukherjee S. In silico studies on the comparative characterization of the interactions of SARS-CoV-2 spike glycoprotein with ACE-2 receptor homologs and human TLRs. J Med Virol. 2020;10.1002/jmv.25987.

75. Dosch SF, Mahajan SD, Collins AR. SARS coronavirus spike protein-induced innate immune response occurs via activation of the NF-KB pathway in human monocyte macrophages in vitro. Virus Res. 2009;142:19-27.

76. Totura AL, Whitmore A, Agnihothram S, et al. Toll-Like Receptor 3 Signaling via TRIF Contributes to a Protective Innate Immune Response to Severe Acute Respiratory Syndrome Coronavirus Infection. Lipkin WI, editor. MBio. 2015; 26;6(3).

77. Berthelot J-M, Lioté F. COVID-19 as a STING disorder with delayed over-secretion of interferon-beta. EBioMedicine. 2020;56:102801.

78. Liu Y, Jesus AA, Marrero B, Yang D, Ramsey SE, Montealegre Sanchez GA, et al. Activated STING in a Vascular and Pulmonary Syndrome. N Engl J Med. 2014 7;371:507-18.

79. Xie J, Li Y, Shen X, et al. Dampened STING-Dependent Interferon Activation in Bats. Cell Host Microbe. 2018;23:297-301.

80. Chen G, Chen D, Li J, et al. Pathogenic role of HMGB1 in SARS? Med Hypotheses. 2004;63:691-5.

81. Schaefer L. Complexity of Danger: The Diverse Nature of Damage-associated Molecular Patterns. J Biol Chem. 2014;289:35237-45.

82. Vogel S, Bodenstein R, Chen Q, Feil S, Feil R, Rheinlaender J, et al. Platelet-derived HMGB1 is a critical mediator of thrombosis. J Clin Invest. 2015;125:4638-54.

83. Andersson U, Ottestad W, Tracey KJ. Extracellular HMGB1: a therapeutic target in severe pulmonary inflammation including COVID-19? Mol Med. 2020;26:42.

84. Nieto-Torres JL, Verdiá-Báguena C, Jimenez-Guardeño JM, et al. Severe acute respiratory syndrome coronavirus $\mathrm{E}$ protein transports calcium ions and activates the NLRP3 inflammasome. Virology. 2015;485:330-9.

This article is protected by copyright. All rights reserved 
87. Xiong $Y$, Liu $Y$, Cao $L$, et al. Transcriptomic characteristics of bronchoalveolar lavage fluid and peripheral blood mononuclear cells in COVID-19 patients. Emerg Microbes Infect. 2020;9:761-70.

88. Bost P, Giladi A, Liu Y, et al. Host-Viral Infection Maps Reveal Signatures of Severe COVID-19 Patients. Cell. 2020;181:1475-88.

89. Li J, Guo M, Tian X, et al. Virus-host interactome and proteomic survey of PBMCs from COVID-19 patients reveal potential virulence factors influencing SARS-CoV-2 pathogenesis. Med (New York, N.Y). 2020 Jul 21. DOI: 10.1016/j.medj.2020.07.002

90. Law HKW, Cheung CY, Ng HY, et al. Chemokine up-regulation in SARS-coronavirus-infected, monocyte-derived human dendritic cells. Blood. 2005;106(7):2366-74.

91. Coperchini F, Chiovato L, Croce L, Magri F, Rotondi M. The cytokine storm in COVID-19: An overview of the involvement of the chemokine/chemokine-receptor system. Cytokine Growth Factor Rev. 2020;53:25-32.

92. Blanco-Melo D, Nilsson-Payant BE, Liu W-C, et al. Imbalanced Host Response to SARS-CoV-2 Drives Development of COVID-19. Cell. 2020;181:1036-1045.e9.

93. Schönrich G, Raftery MJ, Samstag Y. Devilishly radical NETwork in COVID-19: Oxidative stress, neutrophil extracellular traps (NETs), and $T$ cell suppression. Adv Biol Regul. 2020;77:100741.

94. Varga Z, Flammer AJ, Steiger P, et al. Endothelial cell infection and endotheliitis in COVID-19. Lancet. 2020;395:1417-8.

95. He L, Mäe MA, Sun Y, et al. Pericyte-specific vascular expression of SARS-CoV-2 receptor ACE2 - implications for microvascular inflammation and hypercoagulopathy in COVID-19 patients. bioRxiv. 2020 Jan 1;2020.05.11.088500.

96. Cardot-Leccia N, Hubiche T, Dellamonica J, Burel-Vandenbos F, Passeron T. Pericyte alteration sheds light on micro-vasculopathy in COVID-19 infection. Intensive Care Med. 2020;46:1777-8.

97. Wu Z, McGoogan JM. Characteristics of and important lessons from the Coronavirus Disease 2019 (COVID-19) Outbreak in China. JAMA. 2020;323:1239.

98. Molony RD, Malawista A, Montgomery RR. Reduced dynamic range of antiviral innate immune responses in aging. Exp Gerontol. 2018;107:130-5.

99. Cannizzo ES, Clement CC, Sahu R, Follo C, Santambrogio L. Oxidative stress, inflamm-aging and immunosenescence. J Proteomics. 2011;74:2313-23.

100. Ellinghaus D, Degenhardt F, Bujanda L, et al. Genomewide Association Study of Severe Covid19 with Respiratory Failure. N Engl J Med. 2020 Jun 17. doi: 10.1056/NEJMoa2020283

101. van Beek AA, Van den Bossche J, Mastroberardino PG, de Winther MPJ, Leenen PJM. Metabolic Alterations in Aging Macrophages: Ingredients for Inflammaging? Trends Immunol. 
2019 Feb;40(2):113-127. doi: 10.1016/j.it.2018.12.007.

102. Breiman A, Ruvën-Clouet N, Le Pendu J. Harnessing the natural anti-glycan immune response to limit the transmission of enveloped viruses such as SARS-CoV-2. Coyne CB, editor. PLOS Pathog. 2020;16:e1008556.

103. Murray GP, Post SR, Post GR. ABO blood group is a determinant of von Willebrand factor protein levels in human pulmonary endothelial cells. J Clin Pathol. 2020;73:347-9.

104. Guzik TJ, Mohiddin SA, Dimarco A, et al. COVID-19 and the cardiovascular system: implications for risk assessment, diagnosis, and treatment options. Cardiovasc Res. 2020;116: 1666-87.

105. Sidaway P. COVID-19 and cancer: what we know so far. Nat Rev Clin Oncol. 2020;17:336.

106. Pal R, Bhadada SK. COVID-19 and diabetes mellitus: An unholy interaction of two pandemics. Diabetes Metab Syndr Clin Res Rev. 2020;14:513-7.

107. Gebhard C, Regitz-Zagrosek V, Neuhauser HK, Morgan R, Klein SL. Impact of sex and gender on COVID-19 outcomes in Europe. Biol Sex Differ. 2020;11:29.

108. Bonafè M, Prattichizzo F, Giuliani A, Storci G, Sabbatinelli J, Olivieri F. Inflamm-aging: Why older men are the most susceptible to SARS-CoV-2 complicated outcomes. Cytokine Growth Factor Rev. 2020;53:33-7.

109. Niedzwiedz CL, O'Donnell CA, Jani BD, et al. Ethnic and socioeconomic differences in SARSCoV-2 infection: prospective cohort study using UK Biobank. BMC Med. 2020;18:160.

110. Lyn-Cook BD, Xie C, Oates J, et al. Increased expression of Toll-like receptors (TLRs) 7 and 9 and other cytokines in systemic lupus erythematosus (SLE) patients: Ethnic differences and potential new targets for therapeutic drugs. Mol Immunol. 2014;61:38-43.

111. Cai Q, Chen F, Wang T, et al. Obesity and COVID-19 Severity in a Designated Hospital in Shenzhen, China. Diabetes Care. 2020;43:1392-8.

112. O'Shea D, Hogan AE. Dysregulation of Natural Killer Cells in Obesity. Cancers (Basel). 2019;11:573.

113. Schijns V, Lavelle EC. Prevention and treatment of COIVID-19 by control of innate immunity. Eur J Immunol. 2020;50:932-8.

114. Encinar JA, Menendez JA. Potential Drugs Targeting Early Innate Immune Evasion of SARSCoronavirus 2 via 2'-O-Methylation of Viral RNA. Viruses. 2020;12:525

115. Kulkarni AS, Gubbi S, Barzilai N. Benefits of Metformin in Attenuating the Hallmarks of Aging. Cell Metab. 2020;32:15-30.

116. Crouse A, Grimes T, Li P, Might M, Ovalle F, Shalev A. Metformin use is associated with reduced mortality in a diverse population with COVID-19 and diabetes. medRxiv. 2020 Jul 31:2020.07.29.20164020.

117. Menegazzo L., Scattolini V., Cappellari R. The antidiabetic drug metformin blunts NETosis in 
vitro and reduces circulating NETosis biomarkers in vivo. Acta Diabetol. 2018;55:593-601.

118. Rawji KS, Young AMH, Ghosh $\mathrm{T}$, et al. Niacin-mediated rejuvenation of macrophage/microglia enhances remyelination of the aging central nervous system. Acta Neuropathol. 2020;139:893-909. 
Table 1. HCoVs - cell receptors and cofactors aiding viral entry

\begin{tabular}{|c|c|c|c|c|c|}
\hline Virus & $\begin{array}{l}\text { Date emergence } \\
\text { and clinical } \\
\text { manifestations }\end{array}$ & $\begin{array}{l}\text { Primary cell } \\
\text { receptor }\end{array}$ & $\begin{array}{l}\text { Tissue expression of } \\
\text { receptor }\end{array}$ & $\begin{array}{l}\text { Receptors and } \\
\text { co factors } \\
\text { augmenting } \\
\text { viral entry }\end{array}$ & Ref \\
\hline HCoV-229E & $\begin{array}{l}1965 \\
\text { URTI, common } \\
\text { cold }\end{array}$ & APN (CD13) & $\begin{array}{l}\text { Renal and GI epithelia, } \\
\text { synaptic membranes, } \\
\text { pericytes, myeloid } \\
\text { cells, fibroblast like } \\
\text { cells. neurons }\end{array}$ & $\begin{array}{l}\text { TMPRSS2 } \\
\text { TMPRSS11D }\end{array}$ & $(1,2,3)$ \\
\hline HCoV-OC43 & $\begin{array}{l}1967 \\
\text { URTI, common } \\
\text { cold }\end{array}$ & $\begin{array}{l}\text { 9-O- } \\
\text { acetylated } \\
\text { sialic acid }\end{array}$ & $\begin{array}{l}\text { Human epithelial cells, } \\
\text { neurons }\end{array}$ & $\begin{array}{l}\text { IFIT2/IFIT3 } \\
\text { HLA-1 }\end{array}$ & $(4,5)$ \\
\hline SARS-CoV & $\begin{array}{l}2002 \\
\text { Severe acute } \\
\text { respiratory } \\
\text { syndrome } \\
\text { (SARS) }\end{array}$ & ACE2 & $\begin{array}{l}\text { Respiratory, intestinal } \\
\text { epithelial cells, } \\
\text { endothelial cells, renal } \\
\text { tubules, cerebral } \\
\text { neurons, alveolar } \\
\text { macrophages, DCs }\end{array}$ & $\begin{array}{l}\text { cathepsin L, } \\
\text { TMPRSS2/11D } \\
\text { DC-SIGN } \\
\text { (CD206), DC- } \\
\text { SIGNR }\end{array}$ & $(6,7)$ \\
\hline HCoV-NL63 & $\begin{array}{l}2004 \\
\text { Bronchitis URI, } \\
\text { common cold }\end{array}$ & ACE-2 & $\begin{array}{l}\text { Pneumocytes, } \\
\text { intestinal epithelial } \\
\text { cells, endothelial cells, } \\
\text { renal tubules, cerebral } \\
\text { neurons, alveolar } \\
\text { macrophages, DCs }\end{array}$ & $\begin{array}{l}\text { heparan } \\
\text { sulphate } \\
\text { proteoglycans }\end{array}$ & (8) \\
\hline HCoV-HKU1 & $\begin{array}{l}2005 \\
\text { Pneumonia } \\
\text { Common in } \\
\text { children }\end{array}$ & $\begin{array}{l}\text { 9-O- } \\
\text { acetylated } \\
\text { sialic acid }\end{array}$ & $\begin{array}{l}\text { human alveolar type } \\
\text { II cells }\end{array}$ & HLA-C & (9) \\
\hline MERS-CoV & $\begin{array}{l}2012 \\
\text { SARS }\end{array}$ & DPP4 (CD26) & $\begin{array}{l}\text { Intestinal, alveolar, } \\
\text { renal, hepatic and } \\
\text { prostate cells activated } \\
\text { leukocytes }\end{array}$ & furin & (10) \\
\hline
\end{tabular}

This article is protected by copyright. All rights reserved 
SARS, Severe

epithelial cells,

TMPRSS2

disease

endothelial cells, renal

associated with

tubules, cerebral

ageing and

comorbidities

neurons, alveolar

macrophages, DCs

ACE 2 - angiotensin-converting enzyme 2; APN - aminopeptidase N; DCs dendritic cells; DCSIGN - Dendritic Cell-Specific Intercellular adhesion molecule-3-Grabbing Non-integrin (CD209), DC-SIGNR - DC-SIGN receptor; DPP4- dipeptidyl peptidase 4; GI - gastrointestinal; HLA-C - human leukocyte antigen C; IFIT - interferon-induced proteins with tetratricopeptide repeats; TMPRSS - type II transmembrane serine proteases, URTI - upper respiratory tract infection.

Table 2. Immune evasions strategies of genome and encoded proteins of SARS-CoV and (by inference) SARS-Cov-2

\begin{tabular}{|c|c|c|c|c|c|}
\hline Gene & Protein & Function & $\begin{array}{l}\text { Impact on immune } \\
\text { response action }\end{array}$ & Comments & Ref \\
\hline $\begin{array}{l}\text { Reduced } \\
\text { CpG }\end{array}$ & & & $\begin{array}{l}\text { Decreased activity of ZAP } \\
\text { and APOBEC3G. }\end{array}$ & $\begin{array}{l}\text { ZAP expressed in } \\
\text { immune cells. }\end{array}$ & (26) \\
\hline ORF1a & nsp1 & $\begin{array}{l}\text { Mediates RNA } \\
\text { replication and } \\
\text { processing. } \\
\text { Involved in RNA } \\
\text { degradation. }\end{array}$ & $\begin{array}{l}\text { Modulates calcineurin/ } \\
\text { NFAT pathway. Cleaves } \\
\text { host RNA. Inhibits } \\
\text { cyclophilins and } \\
\text { immunophilins. Blocks } \\
\text { ATF2/c-Jun, IRF3 and } \\
\text { IRF7, NFאB, decreases } \\
\text { STAT1 phosphorylation. } \\
\text { Interferes with RIG-1 }\end{array}$ & $\begin{array}{l}\text { Associated with } \\
\text { immune } \\
\text { pathogenicity } \\
\text { and long-term } \\
\text { cytokine } \\
\text { dysregulation. } \\
\text { Promotes host } \\
\text { RNA } \\
\text { degradation. }\end{array}$ & $(27-29)$ \\
\hline
\end{tabular}

This article is protected by copyright. All rights reserved 


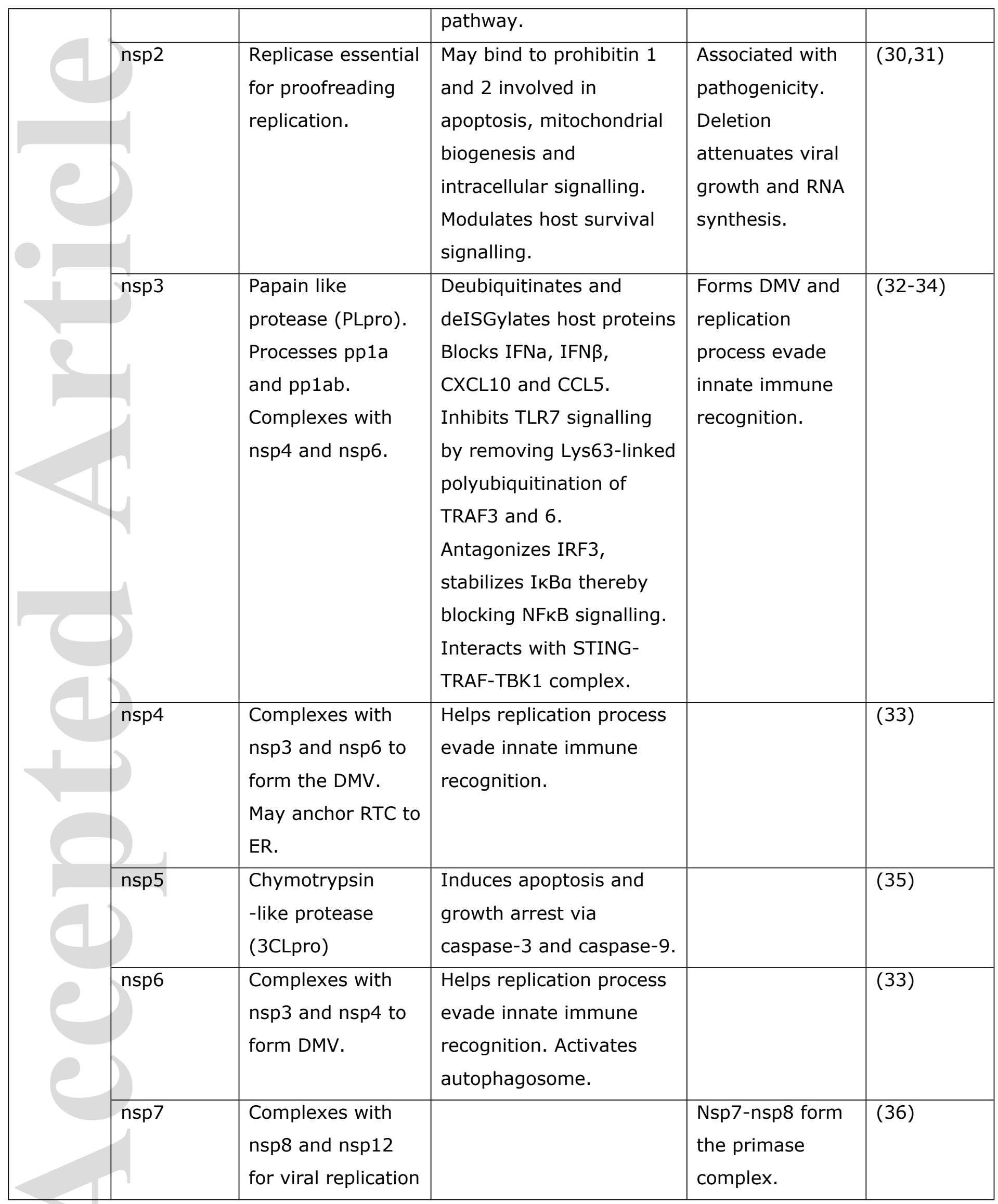

This article is protected by copyright. All rights reserved 


\begin{tabular}{|c|c|c|c|c|c|}
\hline & nsp8 & $\begin{array}{l}\text { Complexes with } \\
\text { nsp7 and nsp } 12 \\
\text { for viral replication }\end{array}$ & & $\begin{array}{l}\text { Nsp7-nsp8 form } \\
\text { the primase } \\
\text { complex. }\end{array}$ & (36) \\
\hline & nsp9 & $\begin{array}{l}\text { Involved in viral } \\
\text { genomic RNA } \\
\text { reproduction but } \\
\text { exact role unclear }\end{array}$ & & $\begin{array}{l}\text { Interacts with } \\
\text { nsp8 }\end{array}$ & $(37,38)$ \\
\hline & nsp10 & $\begin{array}{l}\text { Complexes with } \\
\text { nsp } 1,7 \text { and } 14 . \\
\text { Multifunctional } \\
\text { cofactor in } \\
\text { replication. }\end{array}$ & $\begin{array}{l}\text { Interacts with the oxido- } \\
\text { reductase system causing } \\
\text { cytopathic effect. } \\
\text { Aids RNA capping thus } \\
\text { evades RIG-1 and MDA5 } \\
\text { recognition. }\end{array}$ & $\begin{array}{l}\text { Activator of } \\
\text { nsp14 function. } \\
\text { Forms a complex } \\
\text { with nsp16. }\end{array}$ & $(39-41)$ \\
\hline & nsp11 & $\begin{array}{l}\text { Peptide resulting } \\
\text { from cleavage of } \\
\text { pp1a at nsp10/11 } \\
\text { junction }\end{array}$ & Not known & & \\
\hline $\begin{array}{l}\text { ORF1b } \\
\text { (nsps in } \\
\text { addition }\end{array}$ & nsp12 & $\begin{array}{l}\text { RNA dependent } \\
\text { RNA polymerase } \\
\text { (RdRp) }\end{array}$ & $\begin{array}{l}\text { Targeting mitochondria } \\
\text { limits host cellular } \\
\text { responses }\end{array}$ & & (36) \\
\hline to $1-11$ ) & nsp13 & $\begin{array}{l}\text { helicase key for } \\
\text { efficient } \\
\text { replication of viral } \\
\text { genome }\end{array}$ & $\begin{array}{l}\text { Caps RNA thus evades } \\
\text { RIG-I and MDA-5 } \\
\text { signalling }\end{array}$ & $\begin{array}{l}\text { Failure to trigger } \\
\text { IFIT1. }\end{array}$ & (42) \\
\hline & nsp14 & $\begin{array}{l}\text { exon } 3^{\prime}-5^{\prime} \\
\text { exonuclease plays } \\
\text { crucial role in viral } \\
\text { RNA synthesis and } \\
\text { capping. } \\
\text { Complexes with } \\
\text { nsp10. }\end{array}$ & $\begin{array}{l}\text { Involved in the capping } \\
\text { through its function as a } \\
\text { guanine-N7 } \\
\text { methyltransferase } \\
\text { helping nsp16 evade } \\
\text { RIG-1 and MDA5 } \\
\text { recognition. }\end{array}$ & & (43) \\
\hline & nsp15 & $\begin{array}{l}\text { uridylate -specific } \\
\text { endoribonuclease } \\
\text { (EndU) }\end{array}$ & $\begin{array}{l}\text { Limits exposure of viral } \\
\text { dsRNA to the sensors } \\
\text { MDA5, PKR, and } \\
\text { OAS/RNaseL. Inhibits } \\
\text { poly } U \text { thereby evading }\end{array}$ & & (44) \\
\hline
\end{tabular}

This article is protected by copyright. All rights reserved 


\begin{tabular}{|c|c|c|c|c|c|}
\hline & & & $\begin{array}{l}\text { MDA5 thus antagonizing } \\
\text { IFN-a/ } \beta \text { production. }\end{array}$ & & \\
\hline & & $\begin{array}{l}\text { 2'-O-ribose methyl } \\
\text { transferase } \\
\text { involved in RNA } \\
\text { capping. } \\
\text { Complexes with } \\
\text { nsp10. }\end{array}$ & $\begin{array}{l}\text { Caps RNA thus evades } \\
\text { RIG-I and MDA-5 } \\
\text { signalling }\end{array}$ & $\begin{array}{l}\text { Failure to trigger } \\
\text { IFIT1 }\end{array}$ & $(41,45,46)$ \\
\hline ORF2 & spike & $\begin{array}{l}\text { Heavily } \\
\text { glycosylated with } \\
22 \text { glycans. } \\
\text { ACE/ACE-2 } \\
\text { interaction. } \\
\text { Requires priming } \\
\text { to expose } \\
\text { membrane fusion }\end{array}$ & $\begin{array}{l}\text { Masks immunogenic } \\
\text { protein epitopes. } \\
\text { Induced misbalanced in } \\
\text { RAS that triggers } \\
\text { inflammation. } \\
\text { Masks immunogenic } \\
\text { protein epitopes. }\end{array}$ & & $\begin{array}{l}(22,23,47- \\
49)\end{array}$ \\
\hline ORF3a & ORF3a & $\begin{array}{l}\text { Interact with } \\
\text { SARS-CoV M, S, E, } \\
\text { and 7a proteins } \\
\text { Forms viroporins }\end{array}$ & $\begin{array}{l}\text { Activates PERK pathway, } \\
\text { triggers apoptosis } \\
\text { through expression of } \\
\text { ATF4 and CHOP. } \\
\text { Downregulates and } \\
\text { degrades Type } 1 \text { IFNR. }\end{array}$ & $\begin{array}{l}\text { Expressed on cell } \\
\text { surface. Induces } \\
\text { fibrinogen, stress } \\
\text { pathways, } \\
\text { necrotic cell } \\
\text { death, activates } \\
\text { inflammasome. }\end{array}$ & $(50-52)$ \\
\hline ORF4 & Envelope & $\begin{array}{l}\text { Essential for viral } \\
\text { assembly and } \\
\text { budding. Forms } \\
\text { viroporins. }\end{array}$ & $\begin{array}{l}\text { Induces ROS and } \\
\text { activates inflammasome }\end{array}$ & & $(53,54)$ \\
\hline ORF5 & Membrane & $\begin{array}{l}\text { Important for viral } \\
\text { assembly }\end{array}$ & $\begin{array}{l}\text { Inhibits type I interferon } \\
\text { production by impeding } \\
\text { the formation of TRAF3. } \\
\text { TANK. } \\
\text { TBK1/IKK } \varepsilon \text { complex }\end{array}$ & $\begin{array}{l}\text { Induces } \\
\text { apoptosis }\end{array}$ & $(55-57)$ \\
\hline ORF6 & ORF6 & $\begin{array}{l}\text { Plays a role in } \\
\text { viral pathogenesis, } \\
\text { interacts with } \\
\text { ORF8. May aid }\end{array}$ & $\begin{array}{l}\text { Inhibits STAT1 } \\
\text { nuclear import }\end{array}$ & $\begin{array}{l}\text { Promotes RNA } \\
\text { polymerase } \\
\text { activity }\end{array}$ & (51) \\
\hline
\end{tabular}

This article is protected by copyright. All rights reserved 


\begin{tabular}{|c|c|c|c|c|c|}
\hline & & viral virulence. & & & \\
\hline ORF7a & ORF7a & $\begin{array}{l}\text { Interacts with S } \\
\text { protein and p3a. } \\
\text { Not essential for } \\
\text { replication }\end{array}$ & $\begin{array}{l}\text { Inhibits BST-2 } \\
\text { glycosylation, leading to } \\
\text { a loss of function of BST- } \\
\text { 2. SARS-CoV ORF7a } \\
\text { induces caspase- } \\
\text { dependent apoptosis. }\end{array}$ & $\begin{array}{l}\text { BST-2 restricts } \\
\text { virion egress by } \\
\text { tethering virions } \\
\text { to plasma } \\
\text { membrane. } \\
\text { Interacts with } \\
\text { LFA. }\end{array}$ & $(58,59)$ \\
\hline ORF7b & ORF7b & $\begin{array}{l}\text { Not essential for } \\
\text { viral replication } \\
\text { but structural } \\
\text { component of the } \\
\text { virion. }\end{array}$ & & $\begin{array}{l}\text { It is an integral } \\
\text { membrane } \\
\text { protein located in } \\
\text { the Golgi } \\
\text { compartment. }\end{array}$ & (60) \\
\hline ORF8 & ORF8 & $\begin{array}{l}\text { Differs form other } \\
\text { HCoVs }\end{array}$ & $\begin{array}{l}\text { Interact and } \\
\text { downregulates MHC-I }\end{array}$ & $\begin{array}{l}\text { SARS-CoV } \\
\text { encodes p8a and } \\
\text { p8b that induce } \\
\text { caspase- } \\
\text { dependent } \\
\text { apoptosis and } \\
\text { activates UPR. }\end{array}$ & (61) \\
\hline ORF9 & $\begin{array}{l}\text { Nucleo- } \\
\text { capsid }\end{array}$ & $\begin{array}{l}\text { Stabilises viral } \\
\text { RNA. } \\
\text { Interacts with } \\
\text { stress granules } \\
\text { G3BP1. }\end{array}$ & $\begin{array}{l}\text { Targets MAVS -TRAF3- } \\
\text { TRAF6 and antagonizes } \\
\text { IFN- } \beta\end{array}$ & & $(51,62,63)$ \\
\hline ORF10 & ORF10 & Ubiquitin ligase & unknown & & \\
\hline
\end{tabular}

ACE 2 - angiotensin-converting enzyme 2; BST - bone marrow stromal antigen 2; CHOP C/EBP homologous protein; DMV - double membrane vesicles; HCoV- human coronavirus; IFN - interferon; LFA - Lymphocyte function-associated antigen 1; MAV - mitochondrial antiviral signalling protein; MHC - major histocompatibility antigen; ORF - open reading frame PERK - PRKR-like endoplasmic reticulum kinase; RIG-1 - retinoic acid-inducible gene I; ROS - reactive oxygen species; STAT - signal transducer and activator of transcription; UPR - unfolded protein response; ZAP - zinc finger antiviral protein. 
Table 3. Impact of Innate Immune Suppression on Disease Outcome

\begin{tabular}{|c|c|c|c|}
\hline & $\begin{array}{l}\text { Asymptomatic } \\
\text { or mild }\end{array}$ & Moderate & Severe \\
\hline $\begin{array}{l}\text { Type I/III } \\
\text { IFN }\end{array}$ & $\begin{array}{l}\text { increased and } \\
\text { prolonged } \\
\text { production }\end{array}$ & $\begin{array}{l}\text { moderate } \\
\text { suppression }\end{array}$ & $\begin{array}{l}\text { high and prolonged } \\
\text { suppression }\end{array}$ \\
\hline $\begin{array}{l}\text { Viral } \\
\text { replication }\end{array}$ & limited & mild or chronic & high and sustained \\
\hline $\begin{array}{l}\text { Immune } \\
\text { response }\end{array}$ & $\begin{array}{l}\text { strong and } \\
\text { rapid induction } \\
\text { of adaptive } \\
\text { immunity, viral } \\
\text { clearance. }\end{array}$ & $\begin{array}{l}\text { NK cell and } \\
\text { complement } \\
\text { mediated clearance } \\
\text { of infected cells, } \\
\text { reduced adaptive } \\
\text { immune responses }\end{array}$ & $\begin{array}{l}\text { hyperinflammation, } \\
\text { cytokine storm e.g. IL-6, } \\
\text { IL-8, TNF } \alpha \text {, delayed or } \\
\text { ineffective adaptive } \\
\text { immune response, innate } \\
\text { T cell activity. }\end{array}$ \\
\hline Pathology & $\begin{array}{l}\text { none, sub- } \\
\text { clinical }\end{array}$ & $\begin{array}{l}\text { tissue damage due } \\
\text { to inflammatory } \\
\text { response }\end{array}$ & $\begin{array}{l}\text { viral induced cytotoxicity, } \\
\text { ADCC, complement } \\
\text { mediated damage, } \\
\text { pyroptosis, necroptosis, } \\
\text { neutrophil driven netosis. }\end{array}$ \\
\hline $\begin{array}{l}\text { Vascular } \\
\text { damage } \\
\text { and } \\
\text { thrombosis }\end{array}$ & no & not likely or mild & $\begin{array}{l}\text { highly likely and } \\
\text { contributes to clinical } \\
\text { disease and tissue } \\
\text { damage hence the finding } \\
\text { of high levels of D-dimer } \\
\text { produced to counteract } \\
\text { thrombi formation. }\end{array}$ \\
\hline
\end{tabular}

ADCC - antibody mediate cell cytotoxicity, NK - natural killer 
Table 4. Factors and comorbidities, aberrant innate immune responses and COVID19

\begin{tabular}{|c|c|c|c|}
\hline $\begin{array}{l}\text { Factor or } \\
\text { Comorbidity }\end{array}$ & $\begin{array}{l}\text { Impact on COVID- } \\
19\end{array}$ & $\begin{array}{l}\text { Proposed impact on } \\
\text { innate immune } \\
\text { responses }\end{array}$ & Ref \\
\hline Age & $\begin{array}{l}\text { Increased CFR } \\
>80-14.8 \% \text { vf } 2.3 \% \\
70-79-8.0 \%\end{array}$ & $\begin{array}{l}\text { Increased oxidative } \\
\text { stress, decreased IFN } \\
\text { responses. } \\
\text { Elevated proinflammatory } \\
\text { cytokines. }\end{array}$ & $(97-99,101)$ \\
\hline Blood groups & $\begin{array}{l}\text { Higher risk in blood } \\
\text { group } A \text { and } \\
\text { protective effect in } \\
\text { blood group } 0 \text { in a } \\
\text { cohort of } 1,610 \text { cases }\end{array}$ & $\begin{array}{l}\text { Neutralizing antibodies } \\
\text { against protein-linked N- } \\
\text { glycans on SARS-CoV-2, } \\
\text { or stabilisation of vWF. }\end{array}$ & $(102-103)$ \\
\hline $\begin{array}{l}\text { Cardiovascular } \\
\text { Disease }\end{array}$ & $\begin{array}{l}\text { Increased CFR } \\
10.5 \% \text { vf } 2.3 \%\end{array}$ & $\begin{array}{l}\text { Infection of } \\
\text { cardiomyocytes, Increased } \\
\text { myocarditis, impact of } \\
\text { drugs on RAS. Increase } \\
\text { levels of vWF. }\end{array}$ & $(97,104)$ \\
\hline Cancer & $4.7 \%, 5.6 \%$ & unknown & $(97,105)$ \\
\hline $\begin{array}{l}\text { Diabetes } \\
\text { mellitis }\end{array}$ & $7.3 \%$ & $\begin{array}{l}\text { Reduced ACE2 levels in } \\
\text { diabetes already } \\
\text { predispose to a } \\
\text { proinflammatory } \\
\text { environment. Increased } \\
\text { IL-6 levels. Increased } \\
\text { levels of vWF }\end{array}$ & $(97,106)$ \\
\hline Gender & $\begin{array}{l}\text { Increased CFR for } \\
\text { males across all ages }\end{array}$ & $\begin{array}{l}\text { Differential expression } \\
\text { levels of ACE2, hormonal } \\
\text { regulation of immune } \\
\text { reposes, IL-6 higher in } \\
\text { men }\end{array}$ & $(107,108)$ \\
\hline
\end{tabular}

This article is protected by copyright. All rights reserved 


\begin{tabular}{|l|l|l|l|}
\hline Ethnicity & $\begin{array}{l}\text { Higher risk in some } \\
\text { ethnic groups not } \\
\text { due to socioeconomic } \\
\text { conditions }\end{array}$ & $\begin{array}{l}\text { Difference in TLR } \\
\text { expression, levels of IL-6 } \\
\text { and TNF } \alpha \\
\text { Reduced levels of VitD. }\end{array}$ & $(109,110)$ \\
\hline Obesity & $\begin{array}{l}\text { BMI >25 or } 30 \\
\text { increased risk of } \\
\text { severe pneumonia by } \\
86 \% \text { and } 140 \%\end{array}$ & $\begin{array}{l}\text { Dysregulated NK cells, } \\
\text { increased numbers of } \\
\text { myeloid cells in adipose } \\
\text { tissues and expression of } \\
\text { ACE2 by adipocytes }\end{array}$ & $(111,112)$ \\
\hline
\end{tabular}

ACE 2 - angiotensin-converting enzyme 2; CFR- case fatality ratio; NK cells - natural killer cells; TLR - toll-like receptors; vWF - von Willebrand factor 


\section{FIGURE LEGENDS}

Figure 1. SARS-CoV-2 structure and genome. A) SARS-CoV-2 is a positive-sense RNA enveloped virus with the spike (S), membrane $(M)$, envelope $(E)$ proteins embedded in the lipid envelope, while the nucleocapsid ( $N$ ) protein is associated with the RNA. B) The $5^{\prime}$ end of the genome is comprised of ORFa/ab encoding 2 large polyproteins including the replicase protein crucial for self-generation of the non-structural proteins (nsp) while ORFs 2-10 encode the viral structural proteins (, M, E and $N$ ) and accessory proteins. C) The homotrimers spike proteins of 8-12 nm length are heavily decorated with $\mathrm{N}$-glycans moieties that can be recognised by antibodies, C-type lectins and mannose binding proteins that aid viral attachment to permissible cells, activate the complement system and may be recognised by macrophages and antibodies (D).

Figure 2. SARS-CoV-2 subversion of interferon pathways. SARS-CoV-2 infects permissible cells via the angiotensin converting enzyme two (ACE2). Following infection (A) the virion or viral RNA is sensed by either the cGas/STING pathway where stimulator of interferon genes (STING) engages TBK1, or via retinoid inducible gene I (RIG-I) and melanoma differentiation-associated gene 5 (MDA5). These pathways lead to activation of IRF3 and/or NFkB inducing type I/III IFN that is recognised by IFN receptors (B) and subsequent induction of the interferon stimulated genes (ISGs) and proteins many of which have potent antiviral activities. Based on the knowledge of other coronaviruses especially SARS-CoV, and emerging data from SARS-CoV-2 many of the non-structural, structural and accessory protein subvert and inhibit numerous steps in these pathways thereby inhibiting IFN production allowing increased viral replication.

Figure 3. SARS-CoV-2 activates innate immune pathways. SARS-CoV-2 infects permissible cells via the angiotensin converting enzyme two (ACE2) and is taken by in the endosome where the virus is recognised by Toll-like receptor 7/9 triggering MyD88 pathway, or TLR 3 via the TRIF pathway (A). PAMPS and DAMPS are also recognised by TLR4 (B) or RAGE (D) triggering HMGB1induced damage and NLRP3 inflammasome activation. During viral replication ORF3a and E proteins form viroporins that augment ROS production and inflammasome activation.

Figure 4. SARS-CoV-2 is a vascular and coagulation disease. A) Binding of SARS-CoV-2 to ACE2 blocks ACE2-induced formation of antioxidant angiotensin, facilitating oxygen freeradical formation. Infection in some people also triggers pyroptosis, complement activation 
(B) and hyperinflammation with influx of macrophages, NK cells and neutrophils (C). This self-augmenting cycle triggers further cell damage and DAMPS and PAMPs release as well as ROS production. D) Activation of neutrophils induces neutrophil extracellular traps (NET) aided by the $\mathrm{N}$ protein and generated in response to ROS-induced endothelial cell damage. Disruption of the vascular barrier and endothelial cell exposure to proinflammatory cytokine and ROS increases expression of P-selectin, von Willebrand factor (VWF) and fibrinogen, that attract platelets triggering expression of tissue factor. Together this sequence activates the complement system, one of many pathways that crucially activates the coagulation cascade leading to thrombi formation.

This article is protected by copyright. All rights reserved 


\section{Figure 1}
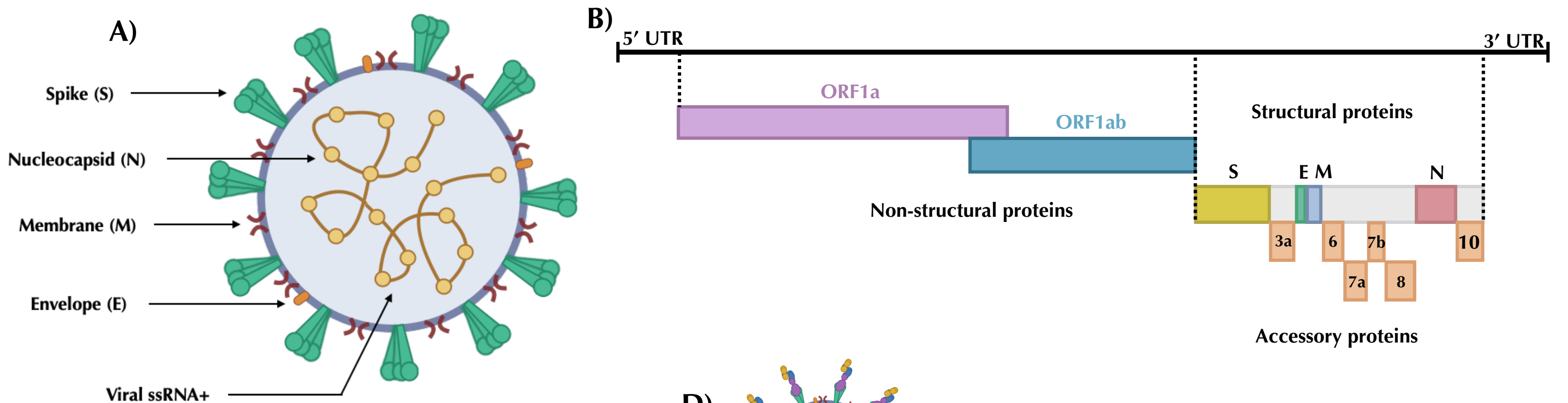

D)

C)
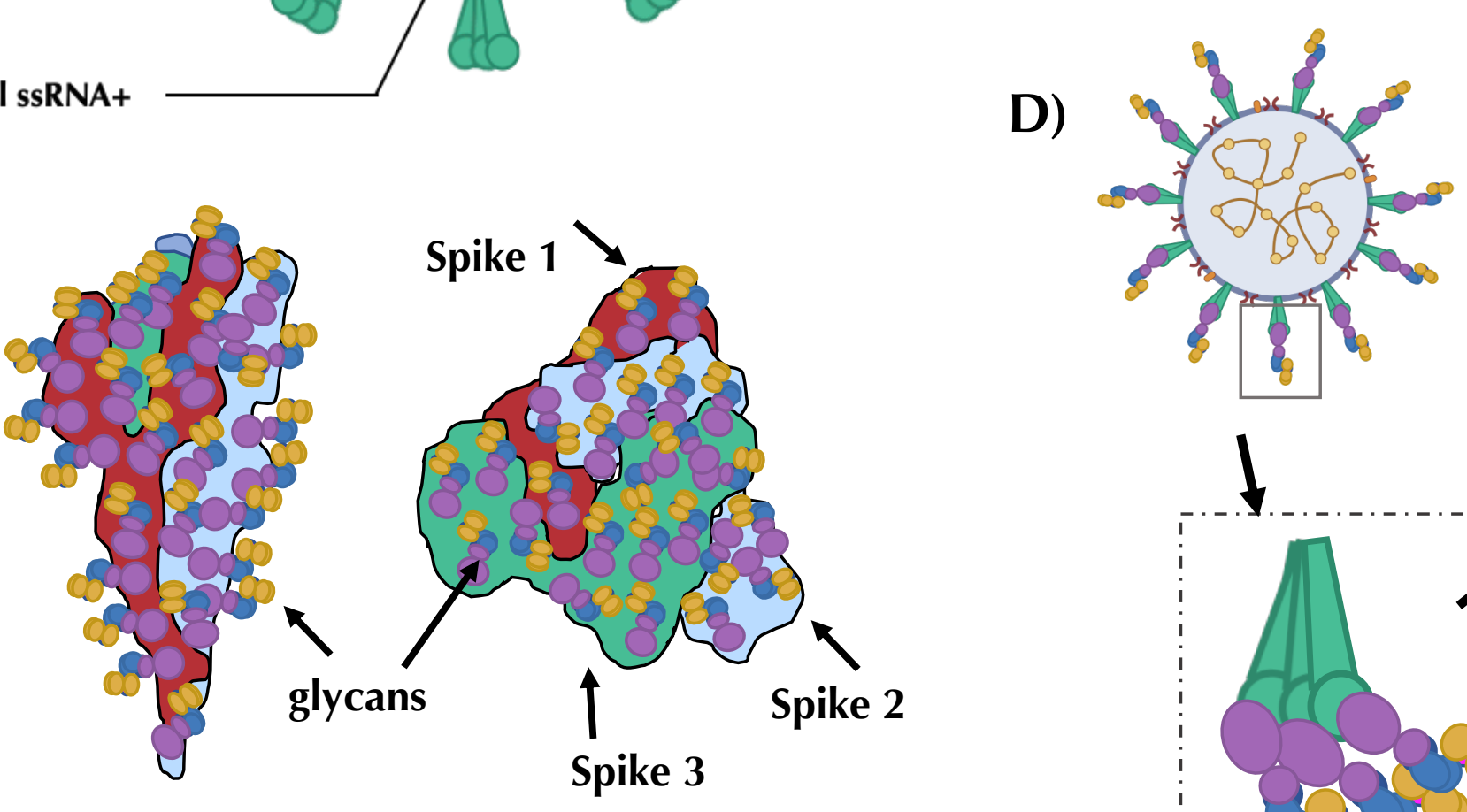

Accessory proteins

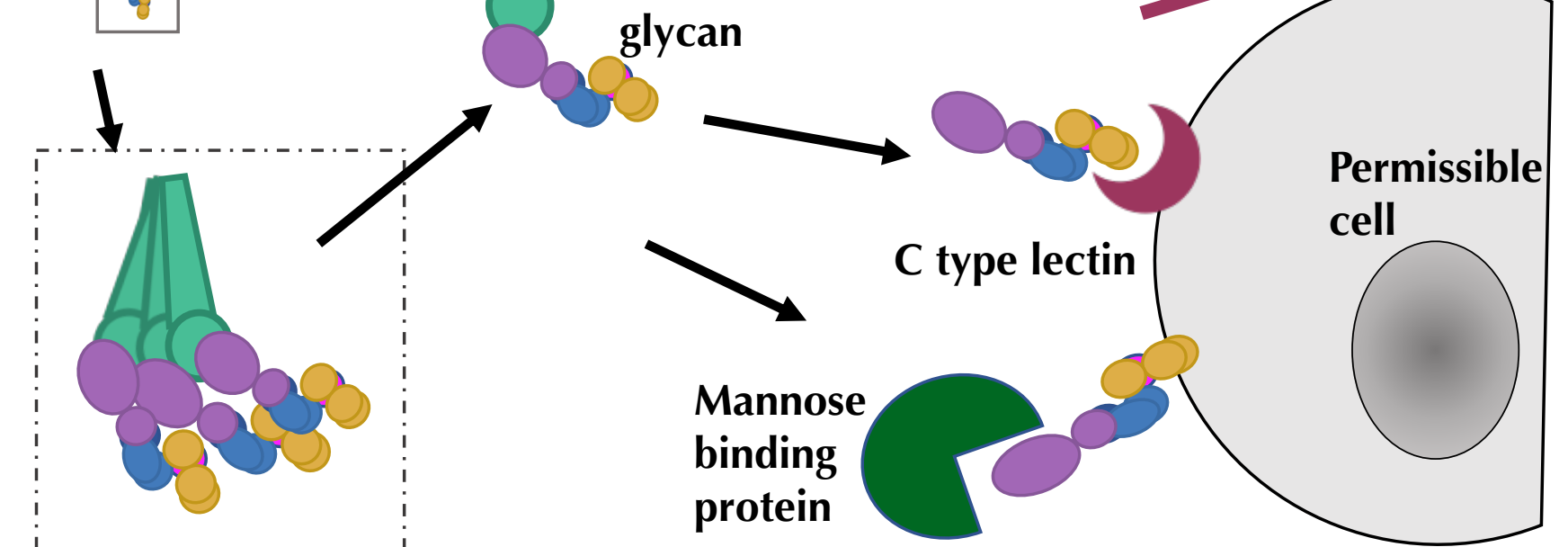


A

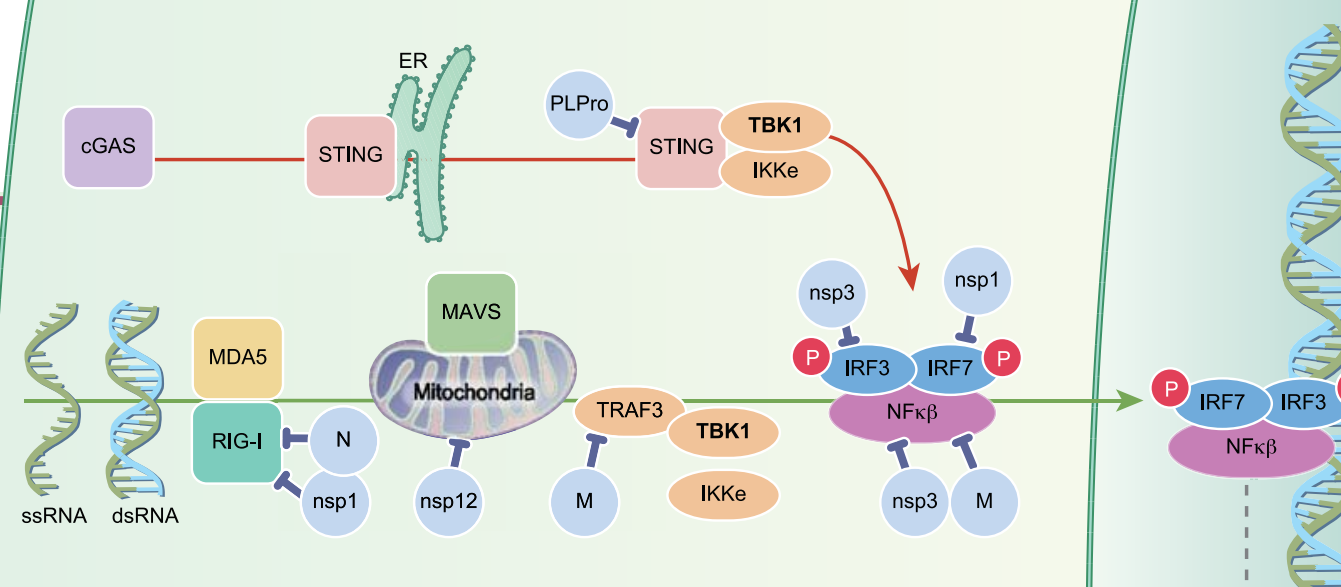

B

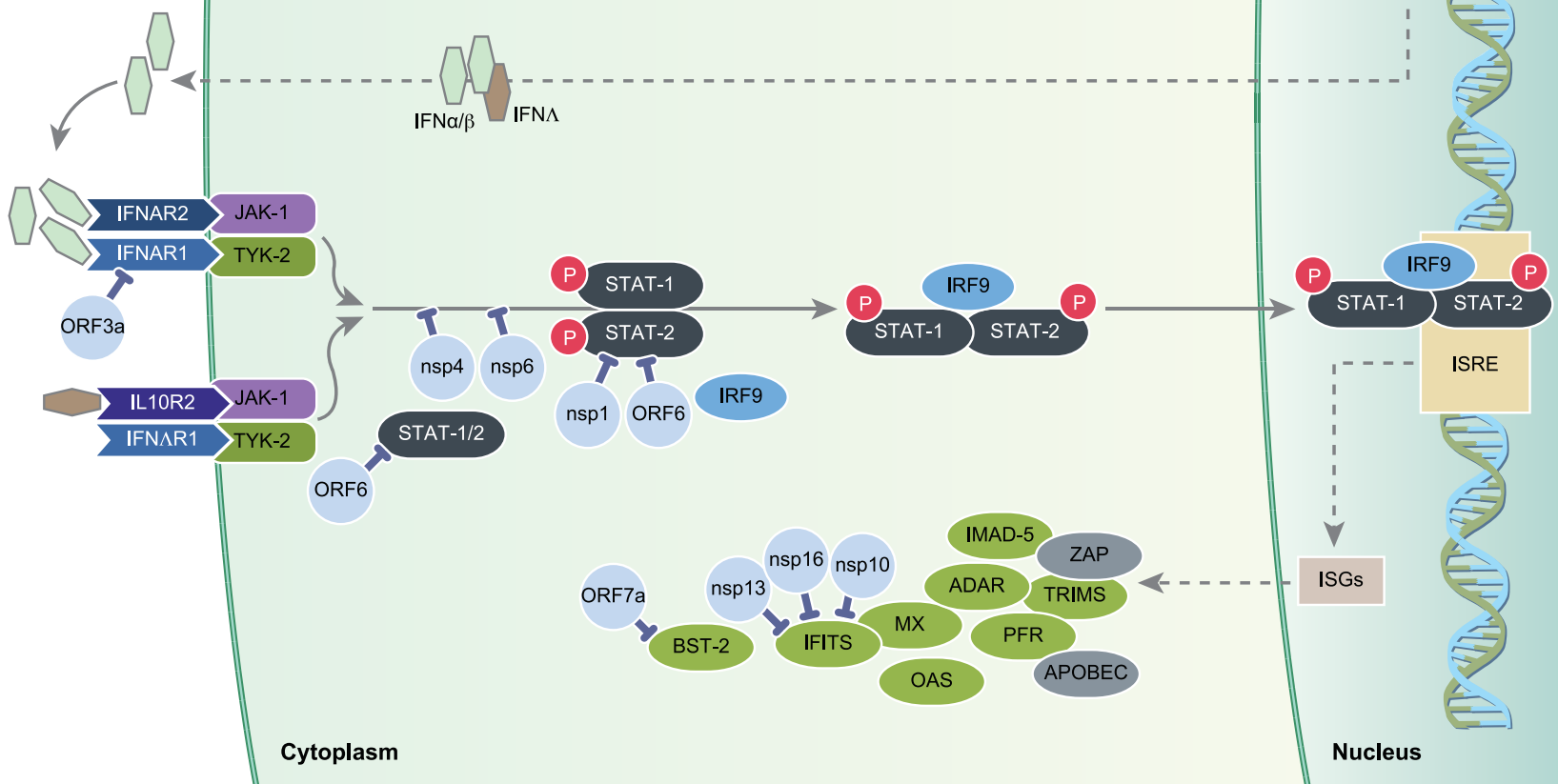



